\title{
P. Skau, Bukshave, og Danmarks Forsvar
}

\author{
Breve \\ til Direktor Bang, Kobenhavn, daverende Formand \\ for Foreningen „Dannebrog”
}

\section{Af A. Svensson}

At de danske Sønderjyder før Genforeningen i høj Grad var interesseret $i$, at man $i$ Danmark opnaaede en forsvarlig Løsning af Forsvarssagen, foreligger der tilstrækkelige Beviser for. Det er en kendt Sag, at fremtrædende Talsmænd for den sønderjydske Befokkning som J. P. Junggreen og Redaktør Jessen i deres Stillingtagen til indre dansk Politik væsentligt lod sig bestemme af Ønsket om, at Danmarks militære Forsvar blev ordnet saa betryggende som muligt. I det efterfølgende vil vi faa et stærkt Indtryk af, at ogsaa en Mand som P. Skau, Bukshave, i sin høje Alderdom var levende optaget af, at dette for ham saa fundamentale Problem blev løst paa tilfredsstillende Maade.

De her i Uddrag gengivne Breve, som beror paa Rigsarkivet, er stilet til Direktør N. Bang, København, daværende Formand for den gamle sønderjydske Landsforening „Dannebrog“. P. Skau, der var født den 5. Juni 1825, var altsaa paa det Tidspunkt, da de første Breve blev skrevet, 82 Aar. Den Iver og Oplagthed, der præger Brevene, og ikke mindre Viljen til ogsaa fysisk at gaa i Brechen for, hvad P. Skau ansaa for ret og rigtigt, vidner om en Vitalitet, som det kun er de færreste beskaaret at være i Besiddelse af saa langt op i Aarene, og de, der endnu mindes P. Skau fra den Tid, vil nikke genkendende til det Billede, han her ubevidst tegner af sig selv. 
Bukshave pr. Fjelstrup, 12. Juni 1907.

Kjære Ven!

Dette faar jeg nok Lov til at kalde Dem?

Tak for sidst, og Tak for Lykønskningen til Fødselsdagen d. 5te d. Siden har vi jo haft det store Aarsmøde i Aabenraa, hvorom De har læst i „Fl. Av.“.

Men nu til en anden Sag.

Den 25. Juni skal der afholdes en Folkefest i en Skov oppe i Nærheden af Trustrup, hvor Banen gaar til Abeltoft. Min Søn, som er Inspektør ved Kolindsund, og flere derboende Præster og Landmænd har foranstaltet den for at kalde Liv i de døde Ben deroppe, som vistnok kan gjøres behov.

Jeg er opfordret til at tale ved denne Lejlighed og har lovet det. Rosenstand fra Vestervedsted skal ogsaa tale deroppe.

Min Søn besøgte mig i Gaar fornemmelig for at tale med mig om Æmnet for mit Foredrag, og det er da, at jeo $i$ store Trakk betegner vi danske Sønderjyders Stilling og Vilkaar i Tiderne samt den nationale Rejsning i Fyrrerne. Paaviser de tyske Løgne ang. Angliternes Behandling i den danske Tid før 1864 samt vor Behandling nu, alt selvfølgelig i store Træk. Men nu kommer Humlen. Jeg fortalte jo min Søn, hvad jeg havde udtalt til H. M. K.... ${ }^{1}$ ) sidst, min Søn er ivrig Forsvarsmand, den Udtalelse, at vi ikke frygter Behandlingen af Prøjserne, hvad enten den bliver menneskelig eller „køllersk“ osv. osv., men saafremt vort gamle Fodreland ikke vil varge sin Selvstændighed, men vil lagge sig blot for den forste, den

1) Kong Frederik VIII. Da de danske S $\varnothing$ nderjyder tog Afsked med Kong Christian IX. ved en Festlighed i Kolding den 7. December 1864, blev det overdraget $P$. Skau at oplæse den til Lejligheden affattede Adresse. Ogsaa ved det paaf $\varnothing$ lgende Taffel var P. Skau Ordfører for de tilstedeværende Sønderjyder, og i sin Skildring af Begivenheden ( Minder fra mit Liv og min Tid ) bemærker han tilsluttende: "For mit personlige Vedkommende havde jeg af dette Afskedsm $\varnothing$ de den Tilfredsstillelse, at Hans Majestæt Kongen og Kronprinsen bevarede mig i deres Erindring og altid senere har givet mig privat Foretræde, naar jeg anmodede derom. $\times$ 
bedste Løbeskytte, saa slaaer de os Vorget ud af Haanden, thi saa kommer det forbandede Ord „hvad kan det nytte“, som hidtil ikke har staaet $i$ vor Ordbog, let frem, thi at søge tilbage til vort Fædreland, naar det har opgivet sig selv, er ikke indbydende osv. osv. osv.

Da Mødet deroppe er bestemt til d. 25. Juni, mente jeg, det var for strengt for mig at være paa Skamlingsbanke til Festen den 24de Juni, men giver Afkald herpaa og istedetfor rejser op til min Søn for at hvile lidt ud om Natten.

Men nu er jeg kommen i Tanker om, at det vistnok vilde faa meget større Betydning, naar jeg fra Talerstolen paa Skamlingsbanke udslynger de føromtalte prcfetiske Ord ang. Moderlandets Forsvarsvilje og vor Stilling (ventelig aplauderet af Tusinder af Sønderjyder, som plejer at give Møde der).

Mon de danske Ministre ikke faar en slig Udtalelse fra dette Sted at see eller høre?

Hvis det maatte have Betydning, at Basunen lød stærkt ira Skamling, saa maatte jeg jo være der og saa holde ud at rejse med Nattog fra Kolding til Trustrup for næste Dag at tale ved denne Fest.

Rosenstand skal nok tale paa Skamling d. 24de og vil rejse om Natten derop. Men han er vel kun halv saa gammel som jeg.

Det er ikke umuligt, at det kunde faa politisk Betydning og virke noget paa høje Vedk, i Moderlandet, thi en slig Udtalelse vil blive modtaget med Begejstring baade af Sønderjyder og andre danske Folk, som søger til dette Sted.

Lad mig snarest høre Deres Mening om denne Sag, og om De ikke nok troer, at Ministrene kan have godt af at faa et sligt Nationalraab fra Sønderjyllands Talerstol!

Hvis saa er, skal jeg holde Touren ud. Undskyld det lange Brev; men De og Deres Frue bedes holde mig tilgode, at jeg ikke kan fatte mig kort, og jeg tegner mig

Deres meget forbundne

P. Skau. 
Brevet -er efter Paategning af Direktør Bang bleven besvaret den 14. Juni. Hvorefter følger nedenstaaende Skrivelse fra P. Skau.

$$
\text { Bukshave pr. Fjelstrup, 19. Juni } 07 .
$$

\section{Kjære Ven!}

Tak for venligt og sympatisk Brev af $14 \mathrm{de} d$.

Ja, jeg kjender og vurderer v. L. Ordsproget „at tale er Sølv“, men „at tie er Guld“; dette overholdt jeg væsentligst ved Aarsmødet i Aabenraa, hvor Ordet fra Medlemmerne ikke burde trykkes, men lyde frit. Derimod troer jeg mere og fastere, at et Alvorsord fra Talerstolen paa Skamling, saaledes som Forholdene ligger, netop vil være et Ord i rette Tid og paa rette Sted og altsaa være Guld.

$\mathrm{Ja}$; jeg frygter næsten for, at ifald jeg forud fik Foretræde hos Konsejlspræsidenten, at han vilde fraraade mig det, thi Mænd i saa høje Stillinger onsker sjælden Assistance fra folkelig Side, ihvor folkelige de end vil være.

Jeg er nemlig sikker paa ,at min event. Udtalelse vil blive modtaget med Jubel, særlig af mine herværende Landsmænd. Jeg vil nu gjøre Aftale med Red. Svendsen²), at han sender Dem "Dannevirke" med Referatet af Talen og saa bede Dem gaa op til Kammerherre Bull ${ }^{3}$ ), som er mig meget bevaagen, og som er meget national, og bede ham bringe H. M. K. den; saa troer jeg derved paa bedste Maade at have røgtet $\mathrm{H}, \mathrm{M}$. K.s Frende bedre end at tale privat til Ministrene, thi det tier de ihjel, naar det passer dem bedst.

Jeg har talt om Sagen med enkelte af mine forstaaende Venner her, og de har indstændig bedt mig om at tale om denne Sag.

Jeg har Talen helt og holdent i Hovedet, og der bliver den, til jeg lader den lyde af al mine Lungers fulde Kraft paa Skam-

2) Nuværende pensioneret Amtsskolekonsulent Nic. Svendsen, Tonder, dengang Redakt $\varnothing \mathbf{r}$ af .Dannevirke*.

3) Kammerherre hos Frederik VIII. 1906-1912. 
lingsbanke. Den gjøre saa, hvad Gavn-den kan, saa har jeg dog gjort mit. Jeg faaer jo rigtignok at rejse op til Trustrup med Nattoget og tale Dagen efter under aaben Himmel, men vor Herre har jo givet mig Kræfter hidindtil, „han hjælper nok herefter"!

Og hermed nok for i Dag.

Jeg er opfordret til at bringe en varm Hilsen fra Johannes Bramsen, som De kjender, ligesom jeg skal takke Dem forbindtligst for den Hilsen, De sendte til min Husbestyrerinde.

En end varmere Hilsen modtage De og Frue fra Deres meget hengivne

$$
\text { P. Skau. }
$$

Brevet besvaret af Direktør Bang den 28. Juni. Men ind imellem havde St. Hans-Mødet paa Skamling fundet Sted, hvor Talernes Rækkefølge var: Pastor Olfert Ricard, København, Pastor Rosenstand, Vester Vedsted, P. Skau, Bukshave, og Pastor Johannes Clausen, Vonsild.

P. Skaus Tale refereres i "Dannevirke" saaledes:

Den sidste Sang (Vor Gud han er saa fast en Borg) stod jeg som tyve Aars Yngling og hørte paa den store Fest her paa Skamling i 1844. Dengang fik jeg min nationale Daab. Gud give, at de unge ogsaa nu maatte tage deres Daab som vi, der dengang var unge. Thi denne Daab har givet sig Udslag indtil den Dag i Dag. (Hør!) Jeg kender ingen, der har svigtet, hvorledes Tiderne end har føjet sig. Tit har de været vanskelige, men naar vi nu i 43 Aar har baaret den Skæbne, som et Folk, der er underkastet et fremmed Herredømme, maa bære, saa har vi haft en Støtte hos vort gamle Fædreland. Thi efter Ulykken tog Danmark sig sammen og udviste en Dygtighed, som har styrket os i vor Kamp, idet vi har kunnet være stolte af nationalt, historisk og kulturelt at tilhøre dette Folk, og denne Følelse kan vi slet ikke undvære.

Det gjorde mig godt, at den sidste Taler saa lyst paa Frem- 
tiden. Thi er man først Genstand for Folks Medlidenhed, saa er man fortabt. Man bør tage sig sammen, saa kommer Kræfterne ogsaa. (Hør!) Jeg har været Medlem af Provinslanddagen for Hertugdømmerne og mindes endnu den stolte Følelse, der greb os, da der nogle Aar efter Nederlaget i 1864 dernede af det tyske Flertal nedsattes en Kommission, der skulde rejse til Danmark for at lære af Dalgas's Plantningsforsøg. (Hør!)

Derfor bringer det Vemod i hver dansk Sønderjydes Sind, og det afføder Harme, naar der i den senere Tid har lydt Røster herovre fra, at Danmark nu er for lille til at hævde sin Selvstændighed eller til at forsvare sin Nationalitet, men gør bedst $\mathrm{i}$ at ligge aabent og kun væbnet med sin Kultur, saa den forste, den bedste rovbegcerlige Løbeskytte kan tage det uden Svcerdslag. Da nedvcerdiger vort gamle Fodreland sig selv; men det gør det endnu mere: det lamslaar os, og i Steden for at støtte os i vor naticnale Forpoststilling slaar det Varget af vor Haand, al den Stund der dog ligger i enhver dansk Sønderjydes Hjerte et Ønske om atter at komme tilbage til det Folk, som vi er skilte fra.

Saa vil det grimme Ord, som hidtil ikke har lydt hos os, komme frem: Hvad kan det nytte at længes tilbage til dette Land, som har opgivet sig selv og derfor om føje Tid maa ligge under. Derfor skal det siges højt og lydt fra dette Sted, fra Skamlingsbanke, saa det kan høres fra højeste Sted til laveste Hytte, at det er ikke Fremmedherredømmet, der kuer os, men vort eget Folk, som vilde svigte os ved at tvivle om sig selv.

Men jeg tror ikke paa disse jammerlige krysteragtige Røster. $\mathrm{Vi}$, som tror paa Gud, vi tror ogsaa paa, at der vil skabes en Ret, der skal afløse den stærkeres Ret, der er knyttet til Jern og Blod. Vi tror ogsaa paa Nationalitetsretten og paa Folkenes Ret til selv at bestemme, hvor de vil høre hen, og hvor de hører hjemme. Gid da denne Aand, hvoraf vi alle var besjælede $\mathrm{i}$ henfarne Dage her ved vore Fester, som begejstrede selve Folket og skabte Aanden i 1848, som tillige havde Frihe- 
den i sit Følge, maa beherske vort Folk og os alle, saa vi ikke skal tvivle om, at „end er Fædrenes Aand i Live“. (Hør! Bravo! Stærkt Bifald!)

Det næste Brev, der er opbevaret fra denne Brevveksling, er skrevet godt halvandet Aar senere og viser, at P. Skau stadig er optaget af samme Sag som sidst.

Kjære Ven!

Bukshave, Fjelstrup, 19. Febr. 1909.

Længe har jeg næret det samme onske at skrive til Dem, men jeg har ventet paa at høre lidt derovre fra om Forsvarssagen, som ligger os alle paa Sinde, ligesom vi alle er enige om, at de Sagkyndige bør følges. Det har gjort et godt Indtryk paa os, at $\mathrm{H}$. M. Kongen udtalte sig herfor til Officererne.

Ligeledes Neergaards korrekte Udtalelse i Thinget.

Det staaer saaledes for os, dersom Landbefæstningen ikke skulde blive iværksat, saa kan det gaa, som da Als blev taget i 1864. Prøjserne gjør Landgang. Lader en Del Folk slaa ihjel, friske rykke frem; de har jo nok af dem og skaaner dem ikke, indtil de naaer Hovedstaden, som ikke kan holdes og heller ikke bør ødelægges.

Saa er Danmarks Selvstændighed „en Saga blott".

Og saa har vor nationale Modstand faaet Knæk, som den aldrig forvinder.

Naar vi ikke længere har vort gamle Fædreland, som selvstændig Stat, at støtte os til, saa vilde det forb. Ord „hvad kan det nytte" komme frem ogsaa hos os.

De prøjsiske Embedsmænds Plagerier og alle de Lidelser, som følger med Fremmedherredømmet, er for intet at regne imod den Følelse, at vort gamle Fædreland tabte sin Selvstændighed som Stat, thi da var vi rodløse, og vort endelige Maal - Gjenforeningen - bortvejret.

Forhaabentlig tager Folket sig sammen, saa min Frygt tør være ugrundet. 
Men jeg har jo oplevet Oprøret fra 1848 og Sejren over samme. Men før 1864 sparede Rigsdagen paa Penge til Forsvarsvæsnet, hvorfor Danmark og vore Sønner maatte bløde.

Gid det ikke maatte gaa ligesaa næste Gang!

Ellers alt vel.

Jeg er legemlig rask, og aandelig - ja - derom kan De selv dømme. Forhaabentlig kommer jeg i April eller Maj til Hovedstaden, og saa ser De mig.

Med Hilsen til Deres elskværdige Frue slutter Deres meget forbundne

$$
\text { P. Skau. }
$$

Fortroligt.

Da De kjender Kammerherre Bull, var det saa ubeskedent af mig, cm De v. L. lod ham faa Kjendskab til dette Brev, for at han muligt kunde fortælle H. M. Kongen om, hvorledes vi ser paa Forsvarssagens Ordning.

Det kan vel ikke gavne stort, men skade kan det dog ikke og muligt bidrage til at glæde $H$. M, at vi har bidt Kjende $i$ Udtalelsen til Officererne. Det kunde maaske bidrage, om aldrig saa lidt, til at stive lidt af.

Men det maa De nu overveje, om De troer, det kan gaa an. Ellers lad det være.

Alt for Sagen!

Deres

P. Skau.

Brevet besvaret af Direktør Bang 7. 3. 1909 med indlagte:

Hr. Direktør.

Amalienborg, 6. 3. 09.

Vedlagt Brevet tilbage - Indholdet interesserede i høj Grad Hans Majestæt.

Med venlig Hilsen

Otto Bull.

Inden Udgangen af 1909 fik J. C. Christensen gennemført den Forsvarsordning, der ikke forblev uden Betydning under den 
første Verdenskrig, og som P. Skau sikkert har hilst med Lettelse og Tilfredshed.

Det sidste Brev fra P. Skau i denne Sammenhæng er dateret 11. Oktober 1910, og nu er Forsvarssagen ogsaa for ham taget af Dagsordenen. Men han er vedvarende paa Farten. Brevet slutter:

For et Par Dage siden kom jeg hjem fra en 10 Dages Tour op til Kolind Sund, hvor min Sønnesøn blev konfirmeret. Han er en velbegavet, sund Dreng, som jeg haaber skal forplante Slægtsnavnet, og som jeg sagde til ham, i hvert Fald ikke sætte nogen Plet paa det. Sidst i Maj Maaned var jeg oppe i Thisted og Omegn og holdt 4 Foredrag. De Folk mødte talrigt, og det bidrog til, at jeg kom godt i Aande.

Det Lefleri med Tyskerne, som jeg finder lovlig meget af i Moderlandet, gik jeg tilfelts imod, idet jeg ad historisk Vej fremstillede for Tilhørerne Sandheden af Grundtvigs Ord:

„Al vor Fortræd er tysk."

Det smagte alligevel Jyderne.

Ellers er det jo de unge Foredragsholdere, som nu bør have Gjerningen, men en enkelt Gang giver den gamle Bjørn et Brum af sig, hvor det tiltrænges.

Her er alt vel. Ogsaa hos vor Ven, Johs. Bramsen og Hustru.

Jeg skal bringe Dem en Hilsen fra min bedagede Husbestyrerinde, ligesom De og Frue og Børn hilses venligst af Deres meget hengivne sønderjydske Ven

$$
\text { P. Skau. }
$$

11. 10. 10 .

E. Sk.

Jeg har faaet mig en Fyldepen. Derved er jeg nu atter $i$ Stand til at skrive nogenlunde.

P. Skau døde 7. Marts 1917, næsten 92 Aar gammel. Han oplevede ikke den Genforening, han saavel som nogen havde arbejdet for cg set hen til.

A. Svensson. 
